\title{
Subacute administration of a TRH analogue (RX77368) in motorneuron disease: an open study
}

\author{
H MODARRES-SADEGHI, H ROGERS, J EMAMI, R J GUILOFF \\ From the Department of Neurology, Charing Cross and Westminster Medical School, Westminster Hospital, \\ London, UK
}

SUMMARY Sixteen patients with motor neuron disease received RX77368, a TRH analogue, IV, repeatedly over 1-12 weeks (median 2 weeks). Slight to moderate improvement in bulbar function, particularly speech, was reproduced or persisted with repeated infusions in 8 of 12 responders over a median of 18 days (range 14-90) during the period of study. Cramps (5/9) and spasticity (5/8) improved for a median of 14 days (range 7-35) and 7 days (range 2-14) respectively. The highest benefit/side effect ratio was seen with $0.2 \mathrm{mg} / \mathrm{kg}(0.15 \mathrm{mg} / \mathrm{kg}$ in those with severe bulbar palsy) every 3-4 days. Long term studies with this analogue in MND are indicated.

The background to the experimental use of thyrotropin releasing hormone (TRH) and analogues in clinical trials in motor neuron disease (MND) has been reviewed recently. ${ }^{1}$ It includes: (1) the presence of TRH in close proximity to motor neurons in the ventral horns of the spinal cord, probably in axonal terminals from descending projections from the brain stem raphe nuclei, (2) the existence of TRH receptors in lamina IX in the ventral horns. In MND its density and distribution is altered with a marked decrease in laminae IX-II (3) Electrophysiological data suggesting an excitatory action of TRH and analogues, probably of a neuromodulatory kind, on anterior horn cells, (4) Neuropharmacological evidence for a role of TRH in motor activity, (5) Beneficial effects of TRH and the analogue CG3509 on the outcome of experimental spinal cord injury, (6) a possible "trophic" effect of TRH on spinal cord cultures and in reducing sciatic neurectomy-induced neuronal loss in the spinal cord of infant rats, (7) reported evidence of transient beneficial effects of TRH in experimental and human spinocerebellar degenerations.

The first report of high dose IV TRH in MND indicated that the beneficial effects seen on weakness, speech, swallowing, cramps, respiration and spasticity were short lived and that marked side effects were seen at the doses used. Trials of TRH analogues with more prominent neuropharmacological actions, longer

Address for reprint requests: Dr R J Guiloff, Department of Neurology, Westminster Hospital, London SW1P 2AP, UK.

Received 23 June 1987 and in revised form 28 March 1988. Accepted 13 May 1988 half-life and higher benefit/side effect ratio were suggested.

In a double blind, randomised placebo controlled study in 25 patients with MND $^{3}$ we showed transient improvement in bulbar functions, decrease in spasticity and changes in muscle force following a single IV dose of RX77368, a stabilised TRH analogue. The longer term effects of this analogue are unknown. The purpose of this open study was to find out (1) The optimum dose and frequency of administration, (2) if the improvements seen can be maintained with acceptable or no side effects and (3) if there are any longer term side effects.

\section{Materials and methods}

Sixteen patients with MND were studied. The criteria for diagnosis and severe incapacity have previously been described. ${ }^{3}$ The first seven patients were responders in previous acute studies, the rest were consecutive patients. Relevant clinical details are summarised in table 1. All patients were admitted to hospital and gave informed consent. The study was approved by the local ethical committee.

RX77368 was provided by Reckitt and Colman Pharmaceutical Division, Hull, UK. The patients received $0 \cdot 1-0 \cdot 35$ $\mathrm{mg} / \mathrm{kg}$ intravenously by an infusion pump (Secura 871704/4). The dose was increased when no response was seen with minimal or no side effects. It was reduced if there were excessive side effects, clinical deterioration or in order to find the minimum dose producing beneficial effects. The dose was changed in $0.05-0.1 \mathrm{mg} / \mathrm{kg}$ steps. No further infusions were given when information about dose, dose interval and reproducibility of response was satisfactory. The first six patients received daily infusions over 6 hours for 7-10 days. The remainder received two to seven 2 hour infusions over 1-12 weeks (table 1) with changes in dose 
Subacute administration of a TRH analogue ( $R X 77368)$ in motorneuron disease: an open study

Table 1 Clinical features of patients treated with $R X 77368$

\begin{tabular}{|c|c|c|c|c|c|c|c|c|c|c|c|c|}
\hline Patient & Age-sex & $\begin{array}{l}\text { Clinical } \\
\text { form }\end{array}$ & $\begin{array}{l}\text { Norris } \\
\text { scale }\end{array}$ & $\begin{array}{l}\text { Time to } \\
\text { severe } \\
\text { incapacity }\end{array}$ & $\begin{array}{l}\text { Duration } \\
\text { of illness }\end{array}$ & $\begin{array}{l}\text { Bulbar } \\
\text { palsy }\end{array}$ & $\begin{array}{l}\text { Tone } \\
U L-L L\end{array}$ & $\begin{array}{l}\text { Weakness } \\
\text { UL-LL }\end{array}$ & Main disability & $\begin{array}{l}\text { Dose } \\
\mathrm{mg} / \mathrm{kg} / \text { infusion }\end{array}$ & $\begin{array}{l}\text { No of } \\
\text { infusions }\end{array}$ & $\begin{array}{l}\text { Period } \\
(\text { Wks })\end{array}$ \\
\hline $\begin{array}{l}1 \\
2 \\
3\end{array}$ & $\begin{array}{l}57 M \\
65 M \\
34 M\end{array}$ & $\begin{array}{l}\text { B } \\
\text { B } \\
\text { ALS }\end{array}$ & $\begin{array}{l}83 \\
93 \\
27\end{array}$ & $\frac{\bar{z}}{16}$ & $\begin{array}{l}14 \\
36 \\
30\end{array}$ & $\begin{array}{l}++ \\
++ \\
++\end{array}$ & $\begin{array}{l}\mathbf{N} \\
\mathbf{N} \\
\mathbf{S}_{2}-\mathbf{S}_{3}\end{array}$ & $\begin{array}{l}0-0 \\
0-0 \\
3-3\end{array}$ & $\begin{array}{l}\text { Dysarthria } \\
\text { Dysarthria } \\
\text { Dysarthria } \\
\text { Tetraplegia }\end{array}$ & $\begin{array}{l}0 \cdot 10-0 \cdot 20 \text { (D) } \\
0 \cdot 20-0.25 \text { (D) } \\
0 \cdot 10-0.25 \text { (D) }\end{array}$ & $\begin{array}{l}10 \\
10 \\
10\end{array}$ & $\begin{array}{l}2 \\
2 \\
2\end{array}$ \\
\hline 4 & $73 \mathrm{M}$ & ALS & 46 & 13 & 19 & ++ & $\mathrm{H}-\mathrm{S}_{2}$ & $2-3$ & $\begin{array}{l}\text { Dysarthria } \\
\text { Tetraparesis }\end{array}$ & $0.20-0.30(\mathrm{D})$ & 7 & 1.5 \\
\hline $\begin{array}{r}5 \\
6 \\
7 \\
8 \\
9 \\
10 \\
11\end{array}$ & $\begin{array}{l}66 \mathrm{M} \\
60 \mathrm{M} \\
54 \mathrm{M} \\
43 \mathrm{M} \\
63 \mathrm{~F} \\
57 \mathrm{~F} \\
36 \mathrm{~F}\end{array}$ & $\begin{array}{l}\text { ALS } \\
\text { ALS } \\
\text { ALS } \\
\text { ALS } \\
\text { ALS } \\
\text { B } \\
\text { ALS }\end{array}$ & $\begin{array}{l}89 \\
73 \\
57 \\
49 \\
73 \\
88 \\
22\end{array}$ & $\begin{array}{l}- \\
36 \\
\frac{36}{13} \\
3\end{array}$ & $\begin{array}{l}36 \\
60 \\
72 \\
42 \\
24 \\
18 \\
14\end{array}$ & $\begin{array}{l}- \\
- \\
+ \\
+ \\
+ \\
+++ \\
++++\end{array}$ & $\begin{array}{l}\mathrm{H}-\mathrm{N} \\
\mathrm{H}-\mathrm{N} \\
\mathrm{H}-\mathrm{H} \\
\mathbf{N}-\mathrm{S}_{2} \\
\mathbf{N} \\
\mathbf{N} \\
\mathbf{S}_{\mathbf{3}}-\mathbf{S}_{3}\end{array}$ & $\begin{array}{l}2-0 \\
2-0 \\
2-3 \\
2-2 \\
1-0 \\
1-0 \\
3-3\end{array}$ & \begin{tabular}{l} 
Arm weakness \\
Arm weakness \\
Paraplegia \\
Tetraparesis \\
Dysarthria \\
Dysarthria \\
Tetraplegia \\
\multicolumn{1}{c}{ Anarthria }
\end{tabular} & $\begin{array}{l}0.20-0.35 \text { (D) } \\
0.25-0.30 \text { (D) } \\
0.20-0.25 \text { (V) } \\
0.20-0.30 \text { (V) } \\
0 \cdot 15-0.25 \text { (V) } \\
0.10-0.20 \text { (V) } \\
0.20-0.25 \text { (V) }\end{array}$ & $\begin{array}{r}8 \\
10 \\
6 \\
7 \\
4 \\
6 \\
2\end{array}$ & $\begin{array}{r}2 \\
2 \\
12 \\
4 \\
2 \\
4 \\
1\end{array}$ \\
\hline $\begin{array}{l}12 \\
13 \\
14\end{array}$ & $\begin{array}{l}53 \mathrm{~F} \\
60 \mathrm{M} \\
61 \mathrm{M}\end{array}$ & $\begin{array}{l}\text { ALS } \\
\text { ALS } \\
\text { B }\end{array}$ & $\begin{array}{l}60 \\
70 \\
27\end{array}$ & $\frac{12}{11}$ & $\begin{array}{r}18 \\
7 \\
17\end{array}$ & $\begin{array}{l}- \\
+++\end{array}$ & $\begin{array}{l}\mathrm{H}-\mathrm{S}_{1} \\
\mathrm{~N}-\mathrm{N} \\
\mathrm{S}_{3}-\mathrm{S}_{3}\end{array}$ & $\begin{array}{l}3-1 \\
1-2 \\
2-2\end{array}$ & $\begin{array}{l}\text { Arm weakness } \\
\text { Paraparesis } \\
\text { Dysarthria } \\
\text { Tetraparesis }\end{array}$ & $\begin{array}{l}0 \cdot 10-0 \cdot 20 \text { (V) } \\
0 \cdot 20-0 \cdot 30 \text { (V) } \\
0 \cdot 10-0 \cdot 20 \text { (V) }\end{array}$ & $\begin{array}{l}5 \\
3 \\
4\end{array}$ & $\begin{array}{l}3 \\
1 \\
2\end{array}$ \\
\hline $\begin{array}{l}15 \\
16\end{array}$ & $\begin{array}{l}45 \mathrm{M} \\
50 \mathrm{~F}\end{array}$ & $\begin{array}{l}\text { ALS } \\
\text { ALS }\end{array}$ & $\begin{array}{l}73 \\
78\end{array}$ & $\overline{12}$ & $\begin{array}{l}10 \\
17\end{array}$ & $\begin{array}{l}++ \\
+\end{array}$ & $\begin{array}{l}\mathrm{S}_{2}-\mathrm{S}_{2} \\
\mathrm{~N}-\mathrm{S}_{1}\end{array}$ & $\begin{array}{l}2-0 \\
1-3\end{array}$ & $\begin{array}{l}\text { Arm weakness } \\
\text { Paraplegia }\end{array}$ & $\begin{array}{l}0 \cdot 15-0.30 \text { (V) } \\
0 \cdot 20-0 \cdot 30 \text { (V) }\end{array}$ & $\begin{array}{l}6 \\
4\end{array}$ & $\begin{array}{l}2 \cdot 5 \\
2\end{array}$ \\
\hline
\end{tabular}

ALS = Amyotrophic lateral sclerosis; B = Bulbar, Bulbar palsy: $+=$ mild,$++=$ moderate $+++=$ severe, $++++=$ anarthric; UL $=$ upper limb; $\mathbf{L L}=$ Lower limb; $\mathbf{D}=$ Daily; $\mathbf{V}=$ Variable dose interval; Weakness (per most affected limb): $0=\mathrm{Nil}, 1=$ Mild, $2=$ Moderate, $3=$ Severe; Tone: $N$ $=$ Normal, $\mathbf{H}=$ Hypotonia, $\mathbf{S}=$ Spasticity $\left(\mathbf{S}_{1}=\right.$ Mild, $\mathbf{S}_{2}=$ Moderate, $\mathbf{S}_{3}=$ Severe $)$. Time in months.

frequency according to the duration of the response seen. Three patients received in addition, blindly, saline infusions during this period.

Neurological examination included detailed assessment of muscle force both with the MRC scale and dynamometry and of muscle tone and fasciculations as previously described. ${ }^{3}$ The muscle groups tested by dynamometry included neck flexion (NF), shoulder abduction (SA), elbow flexion and extension (EF and EE), wrist extension (WE), finger extension (FE), index finger abduction (IFA), thumb abduction (TA), hip flexion (HF), knee extension (KE) and foot dorsiflexion (FD). Very weak or strong muscles were not tested by this method. For further analysis the muscle groups tested have been classified in proximal (SA, EF, EE, HF, KE), distal (WE, FE, IFA, TA, FD), axial (NF), flexor (EF, HF, FD, NF), extensor (EE, WE, FE, KE), upper and lower limbs and hand muscles. Forced vital capacity (VC) was measured with a Wright (Mark 20) respirometer or a portable electronic spirometer. ${ }^{3}$ Peak flow (PF) was measured with a Wright peak flow meter. Maximal expiratory and inspiratory pressure (MEP, MIP) were measured with a specially designed instrument described previously. ${ }^{3}$ These measurements could not be reliably performed in two cases (Nos 10 and 11) with severe bulbar palsy. Bulbar function was also studied in patients with dysarthria by timed measurements of (1) protrusion and lateral movements of the tongue, 10 times each, (2) jaw movements (opening and closing the mouth 10 times), (3) repetition of the words "pepper" and "ticker" 10 times, (4) Maximal sustained elevation of the palate. They were performed in 11 patients except the last test which was done in seven patients. Timed activities of daily living (ADL) ${ }^{4}$ tested included zipping, managing buttons, opening and closing a door, picking up coins, writing a sentence, rising from a chair, and walking 10 yards. They were performed in eight cases, except the last two which were performed in nine. Others had no disability in the limbs or were unable to perform the tests.

The tests were standardised for each individual. To overcome learning effects they were performed repeatedly in the first 2 days. For all quantitative measurements three replications were obtained at each assessment. For maximal isometric voluntary contraction (MVC), respiratory and timed bulbar measurements, eight to 12 baseline assessments were taken over 6-10 days, followed by daily to twice daily (6 and 24 hours after the beginning of infusions) assessments during the infusion period and for a minimum of 1 week after the last infusion. For ADL six baseline assessments over a week were taken and then they were repeated at approximately weekly intervals and 1 week after the last infusion.

Change in speech was scored $(0=$ nil, $1=$ subjective, 2 $=$ also noticed by close relatives and doctor, $3=$ also noticed by others). In addition change in range of jaw, tongue, palate and facial movements was scored by observation (slight, moderate, marked). Swallowing was scored by observation and palpation in a scale from 0 (none) to 5 (normal). Cramps were also scored $(0=$ nil, $1=$ occasional, $2=$ moderate at night and/or day, $3=$ frequent day and night).

Temperature, pulse rate and blood pressure were monitored daily. A full general medical examination and chest radiograph, ECG, FBC, urea and electrolytes, liver function tests, $\mathrm{Ca}++$, phosphate and thyroid function tests were done before and after the infusion period. Thyroid function was also monitored weekly during the infusions.

In addition to recording the patient's subjective response and qualitative clinical assessments, quantitative data were analysed by the following methods:

Method $A$ A value outside 2 SD of mean baseline was accepted as a significant change. ${ }^{3}$ The best of three replications at each assessment was taken. Improvement or deterioration for each parameter was defined as at least two values with significant change in the first 3 days following 
TL

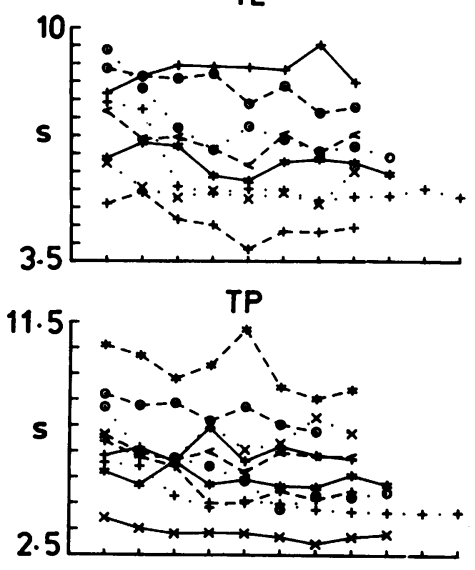

JAW

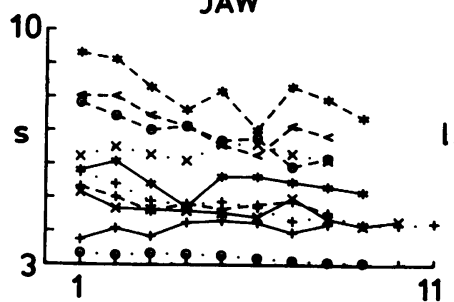

PEP
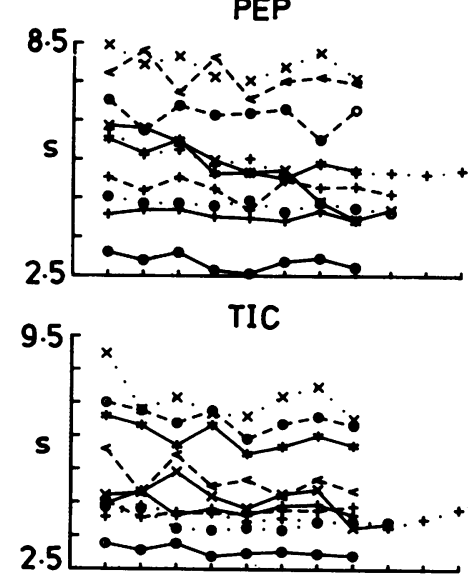

PF

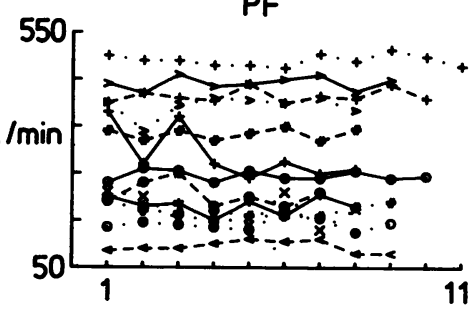

VC
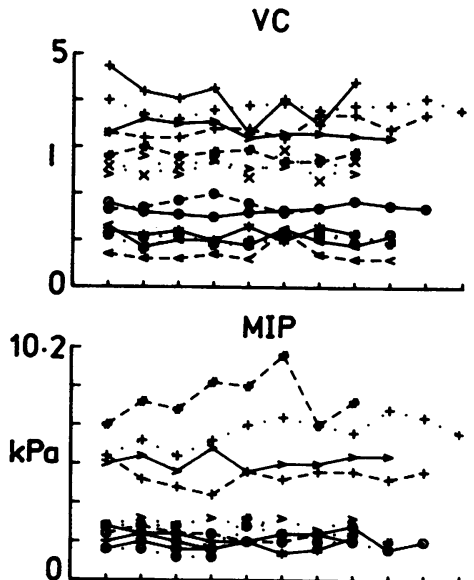

MEP

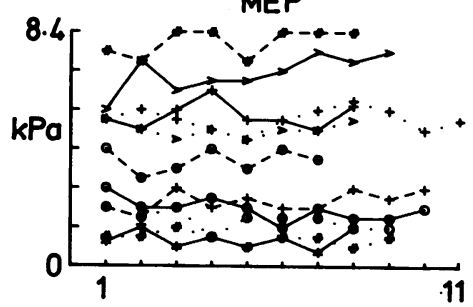

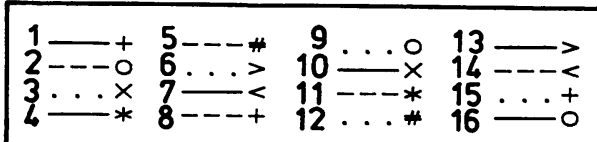

Fig 1 Bulbar function baselines in all patients tested. $X$ axis $=$ assessment number. $Y$ axis $=S I$ units. The baselines for each patient are identified by the code at the bottom. The function tested is identified for each graph: TL = tongue lateral movement; $T P=$ tongue protrusion; $J A W=$ jaw movement $; P E P$ and $T I C=$ repetition of words pepper and ticker; $P F=$ peak flow; $V C=$ vital capacity; MIP and MEP = maximal inspiratory and expiratory pressures. Each assessment is the best of 3 replications (Method A.).

infusions. Bulbar function baselines in all patients are shown in fig 1 . For patients with a change in bulbar function mean baseline and SD is given in table 2. To allow comparison of the degree of change in different patients with widely different baselines, results were expressed as percentage change from mean baseline. To give an idea of the absolute change in each patient and allow comparison between different patients the change was also expressed as SD units from mean baseline (table 2). Bulbar functions were also analysed by the following three methods.

Method $B$ All values during baseline, infusion and post infusion periods were considered as a stationary time series (after first differencing of the series were performed). A cumulative sum test ${ }^{5}$ (Datafit, Oxford University Press) was used to analyse the time series for each bulbar function in each patient at a probability level of alpha $=0.05$ to detect a 1 SD difference from mean baseline. Significant breaks in the time series in the appropriate direction have been classified as improvement or deterioration. A recursive coefficient was also computed for the mean of the series at each assessment point. This method has allowed individualised correction of learning effects (fig 2).

Method C For each bulbar parameter in each patient the effect of all (C1), or individual infusions (C2) on the course of the whole time series was investigated by running a series of regressions. Dummy variables, $d=0$ if no infusion and $d=1$ for the first three values after each infusion were used. $T$ statistics were calculated to evaluate the significance $(p<0.05)$ of the dummy variables in each regression.

Six measures of agreement $\left(P_{0}, P_{s}, P_{s}, A, \lambda_{r} \text { and } \bar{K}\right)^{6}$ were used to compare the results of methods $B, C 1$ and $C 2$ with method A.

\section{Results}

Twelve of 16 patients reported some subjective benefit from the drug. The main improvements were in 

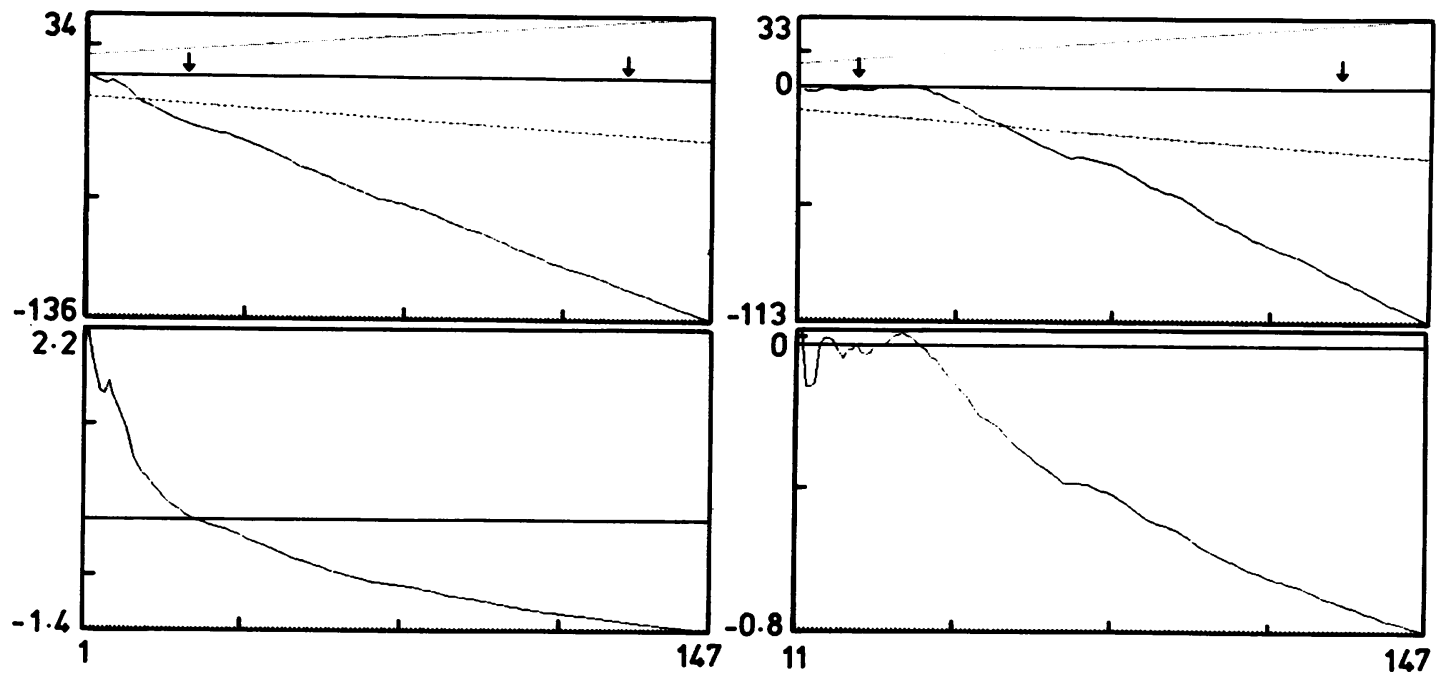

Fig 2 Learning effect. Cumulative sum. Tongue protrusion (Case-8). Left column: without removing learning effects. Right column: after removing learning effects from baseline. Upper graphs: $Y$ axis = cusum of residuals with respect to mean baseline shown for the whole time series. $X$ axis = serial number in the time series. The arrows indicate first and last infusion. Baseline period $=10$ days. Post infusion period $=7$ days. The $V$ shaped lines represent critical bounds at $5 \%$ significance level for $1 S D$ from mean baseline. Lower graphs: $Y$ axis plots the difference of each value from the mean of the process to that point. The upper left graph shows a significant structural break in the time series by point 13, that is, the cusum falls below critical bounds suggesting improvement (less time to perform the test). However, the lower left graph shows a steady decline in the mean of the process during baseline indicating that a significant learning effect was present. The right upper plot shows that when the first 10 of the 24 baseline values are removed the baseline is steady; and there is still a significant structural break after the onset of infusions. The difference of each value from the mean of the process to that point now fluctuates around 0 during baseline (right lower graph).

Table 2 Patients with change in speed of repetitive tongue or jaw movements, word repetition and in timed sustained elevation of palate during subacute administration of a TRH analogue ( $R X 77368)$

\begin{tabular}{|c|c|c|c|c|c|c|c|c|c|c|c|c|}
\hline \multirow[b]{2}{*}{$\begin{array}{l}\text { Case } \\
\text { No }\end{array}$} & \multicolumn{4}{|c|}{ Tongue movements } & \multicolumn{4}{|c|}{ Word Repetition } & \multicolumn{2}{|c|}{ Jaw movement } & \multicolumn{2}{|c|}{ Palate movement } \\
\hline & $\begin{array}{l}\text { Lateral } \\
\text { Magnit }\end{array}$ & Dur & $\begin{array}{l}\text { Protrusion } \\
\text { Magnit }\end{array}$ & Dur & $\begin{array}{l}\text { Ticker } \\
\text { Magnit }\end{array}$ & Dur & $\begin{array}{l}\text { Pepper } \\
\text { Magnit }\end{array}$ & Dur & Magnit & Dur & Magnit & Dur \\
\hline 1 & $\begin{array}{l}3.0(2.4-6.3) \\
(8.8 \text { SD } 0.4)\end{array}$ & 9 & $\begin{array}{l}5.4(2 \cdot 1-6 \cdot 6) \\
(6 \cdot 4 \text { SD } 0.3)\end{array}$ & 17 & $\begin{array}{l}2 \cdot 6(2 \cdot 1-3 \cdot 6) \\
(4 \cdot 3 \text { SD } 0 \cdot 2)\end{array}$ & 15 & $\begin{array}{l}4 \cdot 4(2 \cdot 2-6 \cdot 0) \\
(4 \cdot 1 \text { SD } 0.1)\end{array}$ & 17 & $\begin{array}{l}2 \cdot 8(2 \cdot 2-3 \cdot 3) \\
(4 \cdot 1 \text { SD } 0.2)\end{array}$ & 14 & $\begin{array}{l}\mathrm{NC} \\
(24 \mathrm{SD} 4 \cdot 1)\end{array}$ & \\
\hline 2 & $\begin{array}{l}5.1(2.9-9.8) \\
(8.3 \text { SD } 0.5)\end{array}$ & 80 & $\begin{array}{l}2 \cdot 2(2 \cdot 1-2 \cdot 5) \\
(7 \cdot 3 \text { SD } 1 \cdot 1)\end{array}$ & 67 & $\begin{array}{l}6.6(2 \cdot 3-7 \cdot 5) \\
(7.1 \text { SD } 0.4)\end{array}$ & 80 & $\begin{array}{l}4.7(2.4-6.5) \\
(6.6 \text { SD } 0.3)\end{array}$ & 80 & $\begin{array}{l}4.0(2.8-4.7) \\
(6.8 \text { SD } 0.6)\end{array}$ & 80 & ND & \\
\hline 3 & $\begin{array}{l}3.3(2.6-3.7) \\
(5.5 \text { SD } 0.4)\end{array}$ & 4 & $\begin{array}{l}\text { NC } \\
\text { (7 SD 0.6) }\end{array}$ & & $\begin{array}{l}2.2(2 \cdot 1-2.7) \\
(7.6 \text { SD } 0.8)\end{array}$ & 4 & $\begin{array}{l}3.7(2.1-5.9) \\
(7.9 \text { SD } 0.4)\end{array}$ & 5 & $\begin{array}{l}4 \cdot 2(2 \cdot 3-6.7) \\
(6.3 \text { SD } 0.2)\end{array}$ & 10 & $\begin{array}{l}\text { NC } \\
(8.9 \text { SD 2.1) }\end{array}$ & \\
\hline 4 & $\begin{array}{l}2 \cdot 8(2 \cdot 1-4 \cdot 1) \\
(6 \cdot 3 \text { SD } 0.3)\end{array}$ & 2 & $\begin{array}{l}3.0(2.3-3.5) \\
(5.4 \text { SD } 0.3)\end{array}$ & 2 & $\begin{array}{l}2.1(2.4-4.0) \\
(6.5 \text { SD } 0.4)\end{array}$ & 3 & $\begin{array}{l}\text { NC } \\
(5.4 \text { SD 0.4) }\end{array}$ & & $\begin{array}{l}2 \cdot 6(2 \cdot 1-3 \cdot 2) \\
(3 \cdot 1 \text { SD } 0 \cdot 4)\end{array}$ & 4 & $\begin{array}{l}\text { NC } \\
(8 \cdot 4 \text { SD 1) }\end{array}$ & \\
\hline 8 & $\begin{array}{l}\text { NC } \\
(4.6 \text { SD } 0.5)\end{array}$ & & $\begin{array}{l}\text { NC } \\
(5.3 \text { SD 0.9) }\end{array}$ & & $\begin{array}{l}2.7(2 \cdot 1-3 \cdot 5) \\
(4 \cdot 2 \mathrm{SD} 0.3)\end{array}$ & 12 & $\begin{array}{l}\text { NC } \\
(4.8 \text { SD } 0.1)\end{array}$ & & $\begin{array}{l}\text { NC } \\
(4.8 \text { SD } 0.3)\end{array}$ & & $\begin{array}{l}\text { NC } \\
(7.9 \text { SD } 1.5)\end{array}$ & \\
\hline 9 & $\begin{array}{l}\mathrm{NC} \\
(7.3 \text { SD 1.0) }\end{array}$ & & NC & & (3.9 SD 0.3) & & $\begin{array}{l}\text { NC } \\
\text { (4.3 SD } 0.1)\end{array}$ & & $\begin{array}{l}3 \cdot 7(2 \cdot 1-7 \cdot 1) \\
(3 \cdot 2 \text { SD } 0 \cdot 1)\end{array}$ & 11 & $\begin{array}{l}5.5(2 \cdot 1-7.9) \\
(4 \cdot 1 \text { SD } 0.9) 1\end{array}$ & 10 \\
\hline 10 & ND & & $\begin{array}{l}2.8(2 \cdot 1-3.9) \\
(6.7 \text { SD } 0.5)\end{array}$ & 38 & $\begin{array}{l}\text { NC } \\
(4.6 \text { SD } 0.5)\end{array}$ & & $\begin{array}{l}\text { NC } \\
(5.2 \text { SD 0.9) }\end{array}$ & & $\begin{array}{l}3.1(2 \cdot 3-12) \\
(4.6 \text { SD } 0.3)\end{array}$ & 38 & $\begin{array}{l}-2.4(2-3.5) \\
(4.8 \mathrm{SD} 0.9)\end{array}$ & 12 \\
\hline $2_{15}^{14}$ & $\begin{array}{l}\text { NC } \\
(6.9 \text { SD 0.4) } \\
\text { NC } \\
(6.3 \text { SD 1.2) }\end{array}$ & & $\begin{array}{l}3.7(2.9-5.6) \\
(6.4-0.4) \\
\text { NC } \\
(5.0 \text { SD } 0.8)\end{array}$ & 19 & $\begin{array}{l}2 \cdot 1(2 \cdot 1-2 \cdot 3) \\
(5 \cdot 2 \text { SD } 0.5) \\
3 \cdot 5(3 \cdot 3-4 \cdot 8) \\
(4 \cdot 1 \text { SD } 0.2)\end{array}$ & $\begin{array}{l}1 \\
1\end{array}$ & $\begin{array}{l}\text { NC } \\
(7.6 \text { SD 0.4) } \\
\text { NC } \\
(5.6 \text { SD } 0.4)\end{array}$ & & $\begin{array}{l}\text { NC } \\
(7.2 \text { SD } 0.7) \\
2.5(2 \cdot 1-3 \cdot 1) \\
(5.1 \text { SD } 0.4)\end{array}$ & 5 & $\begin{array}{l}\text { NC } \\
(5.8 \text { SD 1.4) } \\
\text { ND }\end{array}$ & \\
\hline
\end{tabular}

For each patient and parameter the first magnitude value is the median and (range) of the best of three replications of all timed measurements outside 2SD of mean baseline during the whole period of infusions. These values are normalised as standard deviation units from mean baseline ( $-=$ deterioration). The second magnitude value, underneath and in brackets, gives the absolute mean baseline, SD (in seconds) for that parameter and patient. MAGNIT = Magnitude. DUR = Maximum duration of response (days), NC $=$ No change, ND $=$ Not done. The time course of changes in tongue protrusion in patients 1,3 and 10 is shown in figure 5. 
Table 3 Results summary

\begin{tabular}{|c|c|c|c|c|}
\hline \multirow[b]{2}{*}{ Case No } & \multicolumn{2}{|l|}{ Subjective } & \multicolumn{2}{|l|}{ Objective* $^{*}$} \\
\hline & Improved & Deter'd & Improved & Deter'd \\
\hline 1 & Sp, swall, cramps & Nil & $\begin{array}{l}\text { Sp, TM, WR, JM, VC, MEP } \\
\text { swall }\end{array}$ & Nil \\
\hline $\begin{array}{r}2 \\
3 \\
4 \\
5 \\
6 \\
7 \\
8 \\
9 \\
10 \\
11 \\
12\end{array}$ & $\begin{array}{l}\text { Sp, swall, cramps } \\
\text { Sp, stiffness } \\
\text { Sp, stiffness } \\
\text { Strength (arms), cramps } \\
\text { Stiffness, cramps } \\
\text { Breathing, Sp, cough } \\
\text { Sp, stiffness } \\
\text { Sp } \\
\text { Sp, swall } \\
\text { Stiffness } \\
\text { Breathing, cough, cramps, } \\
\text { strength walking }\end{array}$ & $\begin{array}{l}\text { Nil } \\
\text { Nil } \\
\text { Strength } \\
\text { Nil } \\
\text { Nil } \\
\text { Nil } \\
\text { Nil } \\
\text { Nil } \\
\text { Nil } \\
\text { Swall, strength } \\
\text { Nil }\end{array}$ & $\begin{array}{l}\text { SP, TM, WR, JM } \\
\text { Sp, spast, TM, WR, JM } \\
\text { Sp, spast, TM, WR, JM } \\
\text { PF, MEP, VC, ADL, MVC } \\
\text { ADL } \\
\text { Sp, VC } \\
\text { Sp, WR, JM Spast (late) } \\
\text { Sp, JM, PM, MIP, VC } \\
\text { Sp, JM, TM, MVC, swall } \\
\text { Spast } \\
\text { VC, MIP, ADL }\end{array}$ & $\begin{array}{l}\text { PF, MEP, MIP } \\
\text { PF, VC } \\
\text { Nil } \\
\text { VC (high doses) } \\
\text { MVC } \\
\text { Nil } \\
\text { MEP, spast (early) } \\
\text { Nil } \\
\text { PM } \\
\text { MVC, swall } \\
\text { Nil }\end{array}$ \\
\hline $\begin{array}{l}13 \\
14 \\
15 \\
16\end{array}$ & $\begin{array}{l}\text { Nil } \\
\text { Sp, stiffness } \\
\text { Sp, stiffness } \\
\text { Sp, strength (legs), walking }\end{array}$ & $\begin{array}{l}\text { Nil } \\
\text { Strength } \\
\text { Nil } \\
\text { Nil }\end{array}$ & $\begin{array}{l}\text { Nil } \\
\text { TM, WR, JM, spast } \\
\text { JM,WR } \\
\text { ADL }\end{array}$ & $\begin{array}{l}\text { MVC } \\
\text { Nil } \\
\text { Nil } \\
\text { Nil }\end{array}$ \\
\hline
\end{tabular}

*For quantitative data method A (see methods) is given.

$\mathrm{Sp}=$ Speech, Swall $=$ Swallowing, Spast $=$ Spasticity (limbs), ADL = Activities of daily life, $\mathrm{TM}=$ Tongue movement, WR $=$ Word repetition, $\mathbf{P M}=$ Palatal movement, $\mathrm{JM}=\mathrm{Jaw}$ movement, $\mathbf{M V C}=$ Maximal isometric voluntary contraction (changes in $\geqslant 3$ muscles and $>30 \%$ of muscles tested), VC = Vital capacity, $\mathbf{P F}=$ Peak flow, MIP = Maximal inspiratory pressure, $\mathrm{MEP}=$ Maximal expiratory pressure.

speech, cramps and spasticity. A summary of all results is shown in table 3.

\section{Bulbar functions}

Speech All 10 patients with dysarthria had various degrees of improvement in their speech. One patient with dysphonia also improved and in another anarthria did not change. Improvement started 1-6 hours after the beginning of infusions. It was described as clearer speech, stronger, less nasal voice, lighter tongue or less effort needed to talk. This change was scored as $\mathbf{3}$ in three patients, as $\mathbf{2}$ in four patients and as 1 in the remaining three. Except for two patients whose speech remained better for 20 and 70 days after the last infusion, the maximum duration of improvement after each infusion ranged from 2 to 7 days (median 4 days). In three patients the response was only seen with the first 2-4 infusions. Of those with improvement in speech it was seen in all with $0.2 \mathrm{mg} / \mathrm{kg}$ or more, in $70 \%$ with $0.15 \mathrm{mg} / \mathrm{kg}$, in $20 \%$ with $0.1 \mathrm{mg} / \mathrm{kg}$ and in none of the patients who received saline $(n=3)$. Increasing the dose above $0.2 \mathrm{mg} / \mathrm{kg}$ did not increase the degree of response or number of responders, although it increased the side effects. Figure 3 shows cumulative sums for word repetition in all patients (Method B).

Respiration Changes in respiratory parameters occured in six of 14 patients tested. Four of them had bulbar signs. VC improved in five patients. In one of them there was initial deterioration with higher doses associated with more side effects followed by improvement with lower doses. In the other VC deteriorated. The time course of these changes is shown in fig 4. Four of these patients also had improvement (33-170\% of mean baseline) in MIP or MEP (patients $1,5,9$ and 10 ). Peak flow deteriorated (up to $37 \%$ ) in two patients. One of them (case 2) was asthmatic and had also deterioration (up to $35 \%$ ) in maximal respiratory pressures, the other (case 3) had significant side effects.

Other Bulbar Functions The range of jaw, tongue and facial movements improved moderately in $4 / 7$ patients who had spasticity of relevant muscles. In one patient jaw clonus disappeared 24 hours after each infusion for 1-2 days. Quantitative measurements of other bulbar functions tested showed changes in 9/11 patients (table 3). Figure 5 exemplifies the time course of changes for tongue protrusion. Swallowing improved (one grade) in three cases (for 1, 17 and 80 days) and deteriorated (one grade) in another (for 1 day).

The number of patients who improved and deteriorated for each bulbar function by methods $\mathrm{A}, \mathrm{B}, \mathrm{Cl}$ and $C 2$ is shown in fig 6. All six measures of agreement $\left(\mathrm{P}_{0}, \mathrm{P}_{\mathrm{s}}, \mathrm{P}_{\mathrm{s}}, \mathrm{A}, \lambda_{\mathrm{r}}\right.$ and $\left.\mathrm{K}\right)$ were consistent. Among these, $\overline{\mathrm{K}}$ has statistical properties and its values were 0.56 (method B), 0.39 (method C1) and 0.29 (method C2). All values of $\bar{K}$ were significant at $p<0.001$ indicating overall agreement in detection of changes in bulbar function by each method relative to method $A$. There was also good agreement in each individual patient between method $A$ and $B(\bar{K}=0.51$, $\mathrm{p}<0.03)$.

Cramps and spasticity Cramps improved significantly from grade 3 to 1 in five of nine patients. This lasted for a median of 2 weeks (range 1-7). 

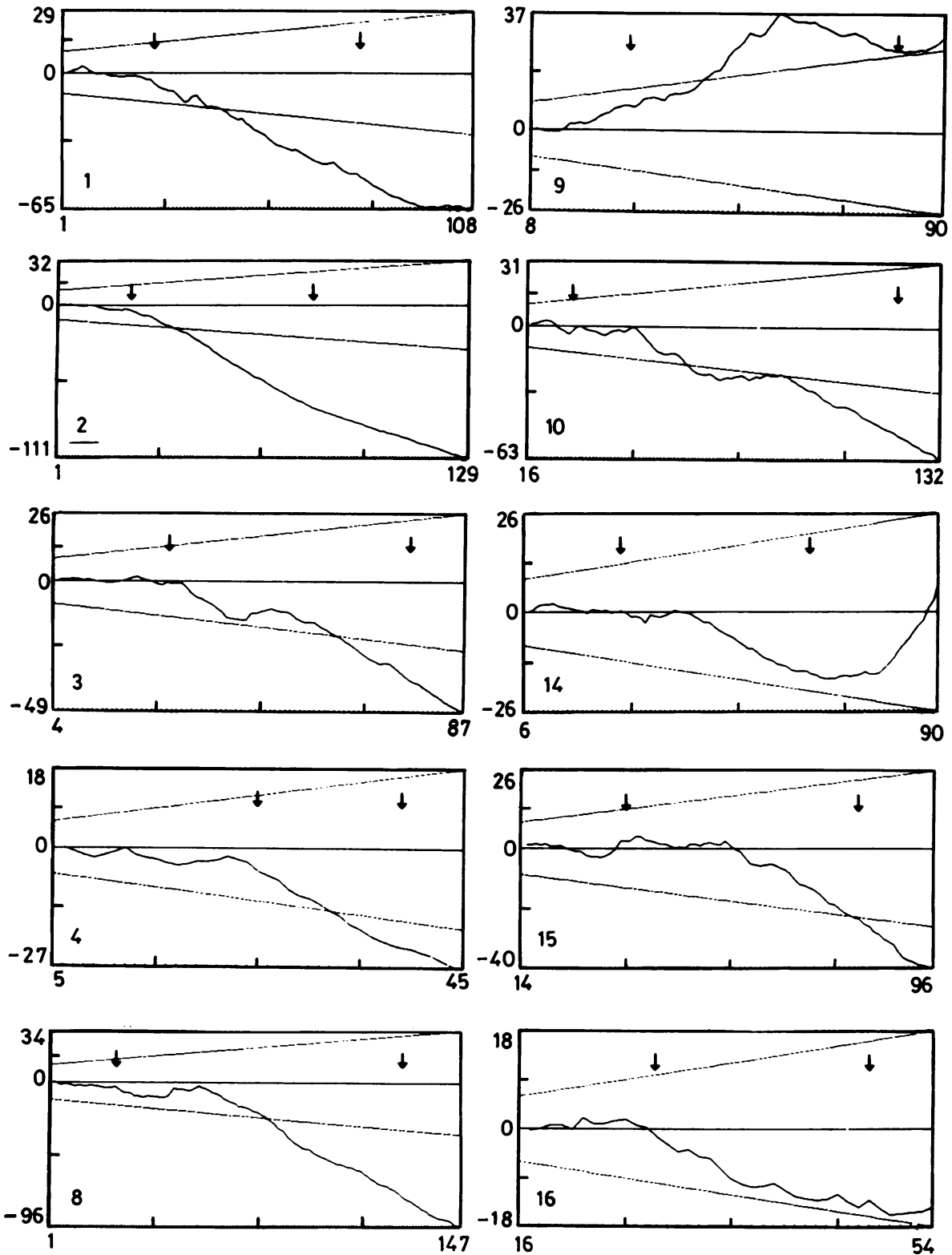

Fig 3 Cumulative sums for word repetition (ticker) in all tested patients. The numbers inside the plot indicate case numbers (table 1). The arrows indicate first and last infusion of RX77368. Note improvement (decrease in time to perform the test resulting in values below critical bounds) in patients $1,2,3,4,8,10,15$. Patient 9 deteriorated and no significant change was seen in patient 14 and 16.

Muscle tone in limbs diminished in five of eight patients with spasticity. This was seen 2-24 hours after the infusions started and lasted for 2-14 days, (median 7). In one (patient 8) with sustained unilateral ankle clonus, spasticity increased with bilateral sus- tained clonus immediately after each infusion and it decreased a day after infusions with disappearance of clonus. Although these changes were associated with better performance in ADL tests in two patients (see over) there were no major functional changes. 

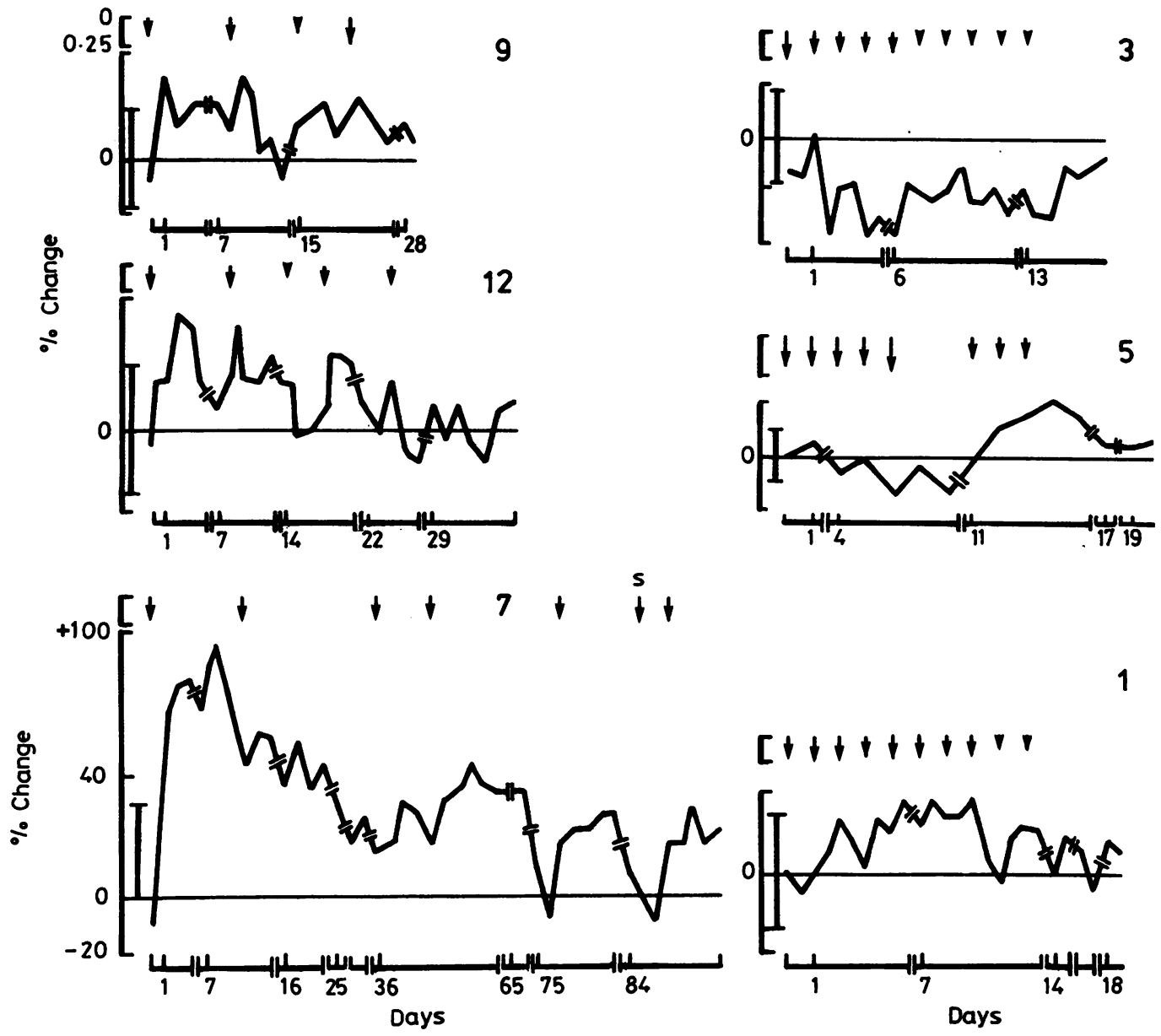

Fig 4 Time course of changes in vital capacity. $X$-axis: Time $Y$-axis: Percentage change from mean baseline (0), +ve = increase, $-v e=$ Decrease. Vertical bars: $2 S D$ of mean individual baseline. Numbers at the top right of each graph show case numbers. Arrows: RX77368 infusions. The size of the arrows correlates with the dose. The dose range $(\mathrm{mg} / \mathrm{kg})$ is shown for case 9 in the left top corner and the scale is the same for other patients. $S=$ Saline. Left column: Note diminution of the response with repeated infusions. Mean VC baselines in patients 9,12 and 7 was $1 \cdot 1,1 \cdot 0$ and 1.0 litres, respectively. Right column: Patient 5 deteriorated initially with higher doses but improved 4 days later with a smaller dose. Patient 1 and 5 had also improvement in maximal expiratory pressures (170\% and 130\%) with a similar pattern. Mean baseline VC in patients 3,5 and 1 was $2 \cdot 6,2.9$ and $4 \cdot 1$ litres respectively. Method A.

Muscle force There were no significant changes in MRC grading. Out of 137 muscles tested serially in 13 patients (median 18 days) with dynamometry, MVC changed at least twice during the whole infusion period in $46 \%$ (18\% improved, $28 \%$ deteriorated). The proportion of muscles changing in different subgroups were flexors $63 \%$, extensors $42 \%$, proximal $48 \%$, distal $35 \%$, axial $64 \%$, upper limbs $41 \%$, lower limbs $48 \%$ and hand $25 \%$. Changes in three or more muscles and more than a third of muscles tested was seen in 5/13 patients (improvement in two cases, deterioration in three). The percentage of muscles which changed repeatedly with at least three infusions was $27 \%$ (12\% improved, $15 \%$ deteriorated). The maximum duration of improvement or deterioration was 5 and 8 days respectively. Deterioration was more often seen with doses associated with more side effects. These changes were of no major functional 


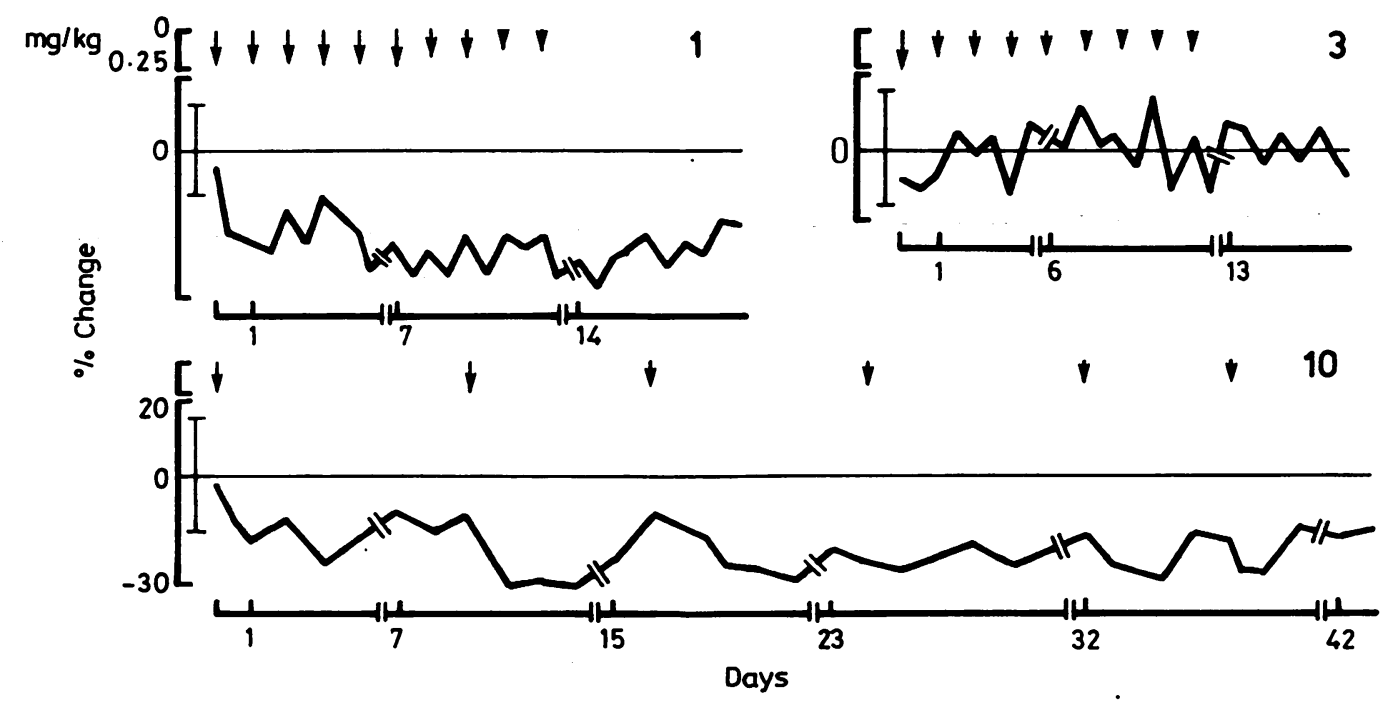

Fig 5 Time course of changes in timed tongue protrusion. The layout of the graphs is similar to fig 4. -ve = Decrease in time, that is, improvement. Note that improvement in case 1 starts immediately after the first infusion and lasts about a week after the last one. Also note temporal relationship of the response to each infusion in case 10 and that it was maintained for nearly 5 weeks. Case 3 showed no change. Method A.

significance. Figure 7 exemplifies the time course of changes in MVC in all muscles tested in two patients. $A D L$ Of nine patients suitable for ADL testing, two with moderate weakness in upper limbs (mild spasticity in one) showed improvement in timed zipping and/or buttoning during the infusions. Two patients with moderate weakness (mild spasticity in one) in the legs showed improvement in timed walking and rising from a chair (one only with the first three infusions, the other up to a week after the last infusion). There was subjective improvement in three of these patients. No subjective or objective changes were noted after saline infusions.

Other changes Fasciculations increased in six patients during infusions and decreased in two approximately 1 day after infusion's. No changes were seen in reflexes or plantar responses. Norris scale did not change during or after infusions.

Thyroid function Patient 7 was hypothyroid and his T4 remained unchanged. In the others, weekly serum T4 $(n=54)$ and T3 $(n=34)$ measurements were made. There was a median increase of $28.5 \%(n=28$, range $-13 \%$ to $+130 \%)$ and $72 \%(n=18$, range 0 to $170 \%$ ) compared to baseline in serum T4 and T3 respectively 24 hours after individual infusions. On 10 occasions (nine patients) these were above the normal range. The measurements $\mathbf{4 8}$ hours or more after the infusions showed a median change of $-8 \%(n=26$, range $-47 \%$ to $33 \%)$ for T4 and $+7 \%(n=16$, range $-33 \%$ to $+80 \%$ ) for $\mathrm{T} 3$. Serum $\mathrm{T} 3$ remained within normal range. TSH increased temporarily in two patients and was suppressed (below normal range) in half of the patients remaining so up to one week after the last infusion. There was no relationship between rise in serum thyroxine and clinical response or severity of side effects.

Adverse effects Side effects included shivering and hot and cold feelings $(n=16$ each); tickling in the throat $(n=12)$; cough, nausea $(n=11$ each); excessive tiredness $(n=10)$; sweating $(n=8)$; hypersalivation $(n=7)$; rhinorrhea, dryness of the mouth $(n=4$ each); excessive yawning $(n=3)$; vomiting, itching, urgency and frequency of micturition $(n=2$ each); thirst and heartburn ( $n=1$ each). Moderate to severe side effects were seen in $58 \%$ with doses above $0.2 \mathrm{mg} / \mathrm{kg}$, in $40 \%$ with $0.2 \mathrm{mg} / \mathrm{kg}(5 / 6$ had severe bulbar palsy), only in one patient $(17 \%)$ with severe bulbar palsy with $0.15 \mathrm{mg} / \mathrm{kg}$ and in none with $0.1 \mathrm{mg} / \mathrm{kg}$. They were predominantly seen during and within 1 hour after the infusions but occasionally continued for up to 14 hours. In patients with repeated daily infusions the intensity of side effects decreased with each infusion in the first 3 to 6 days and then increased again. This was less evident in patients with longer interval between infusions.

There was no change in BP, pulse and oral temperature outside the normal range except for a temporary increase in BP in a patient with a history of 


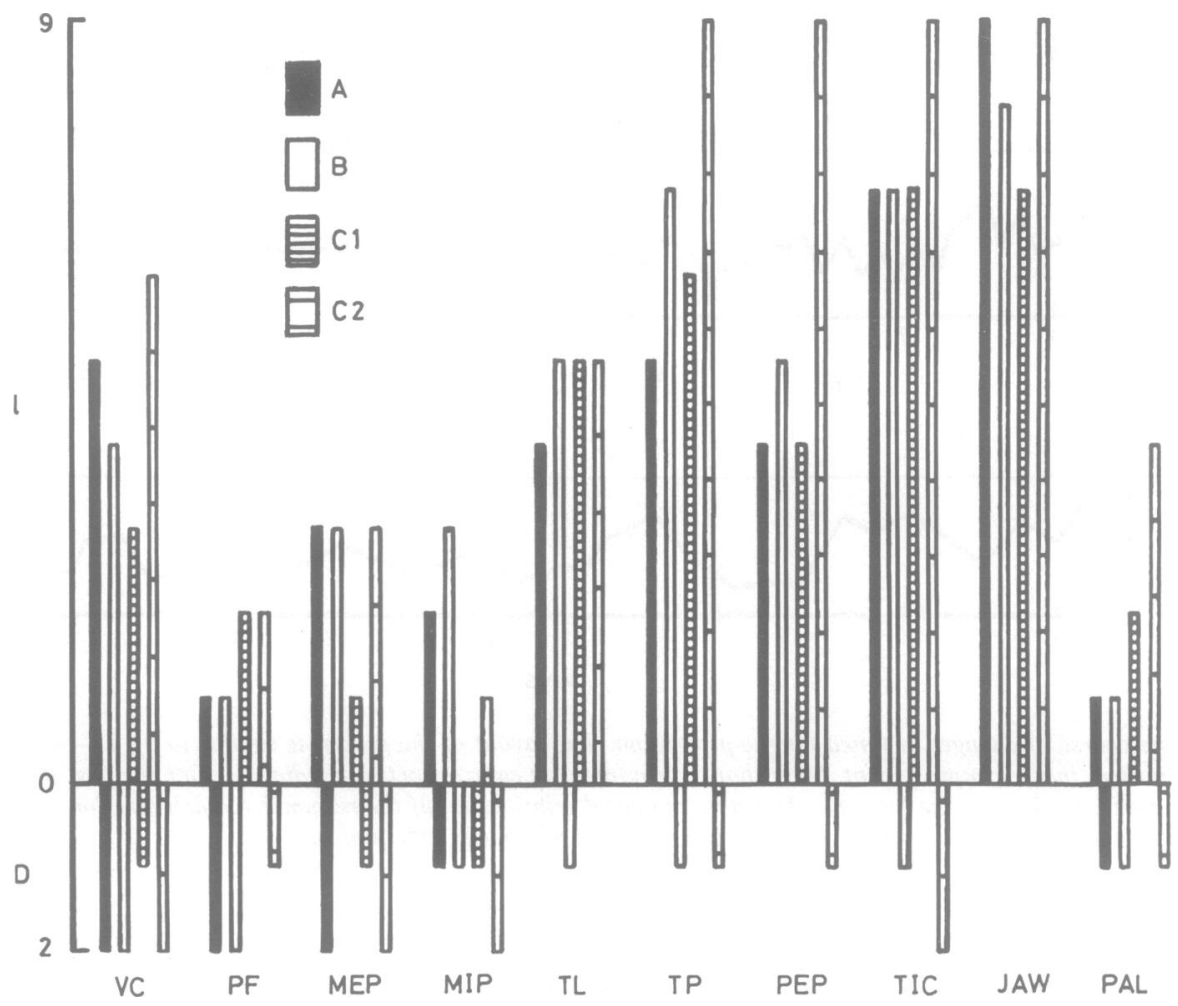

Fig 6 Comparison of frequency distribution of improvement and deterioration in bulbar functions by four methods: $Y$ axis $=$ number of patients improving $=I$ (above 0 ) or deteriorating $=D$ (below 0). $X$ axis = functions tested (abbreviations as in fig 1). For a description of methods $A$, $B, C 1$ and $C 2$ see methods. Cases with both deterioration and improvement with different infusions are shown twice.

hypertension. There was no change in liver function tests, FBC and urea and electrolysis during or after infusions.

\section{Discussion}

The changes in speech, respiration, muscle force and spasticity observed in this study are similar to our previous acute controlled trial. ${ }^{3} \mathrm{~A}$ biological rather than a placebo effect is also supported by (1) the temporal relationship of the changes to the infusions, (2) the reproducibility of the response, (3) the lack of response to small doses and to saline infusions, (4) the associated objective findings, (5) the magnitude of the responses seen was beyond the degree of placebo effect observed in our previous controlled study. We have not seen significant improvement in speech or respiration with placebo. In addition, repeated exercise tests in the first 2 days followed by a prolonged baseline made any significant learning effect less likely. When they still occurred, individual correction of the baselines with the cumulative sum test, still yielded similar overall results to the other two methods of analysis used (see methods).

Improvement in speech could be maintained in eight of 12 patients who responded for up to 3 months. Two of the three who improved only with the first 2-4 infusions had them daily. Improvement in tongue or jaw (or palate in one patient) movements was only seen in patients with spasticity of relevant muscles and correlated with changes in speech. Improvement in VC in five patients lasted for a maximum of 3 days after the infusions except in one patient in whom it was maintained for 3 months. Both the loss of response in speech with daily infusions and the less evident changes in VC with repeated infusions suggest receptor down regulation ${ }^{78}$ and highlight the importance of careful choice of frequency of administration in future large scale longer term studies.

Deterioration in peak flow and VC was seen in two 

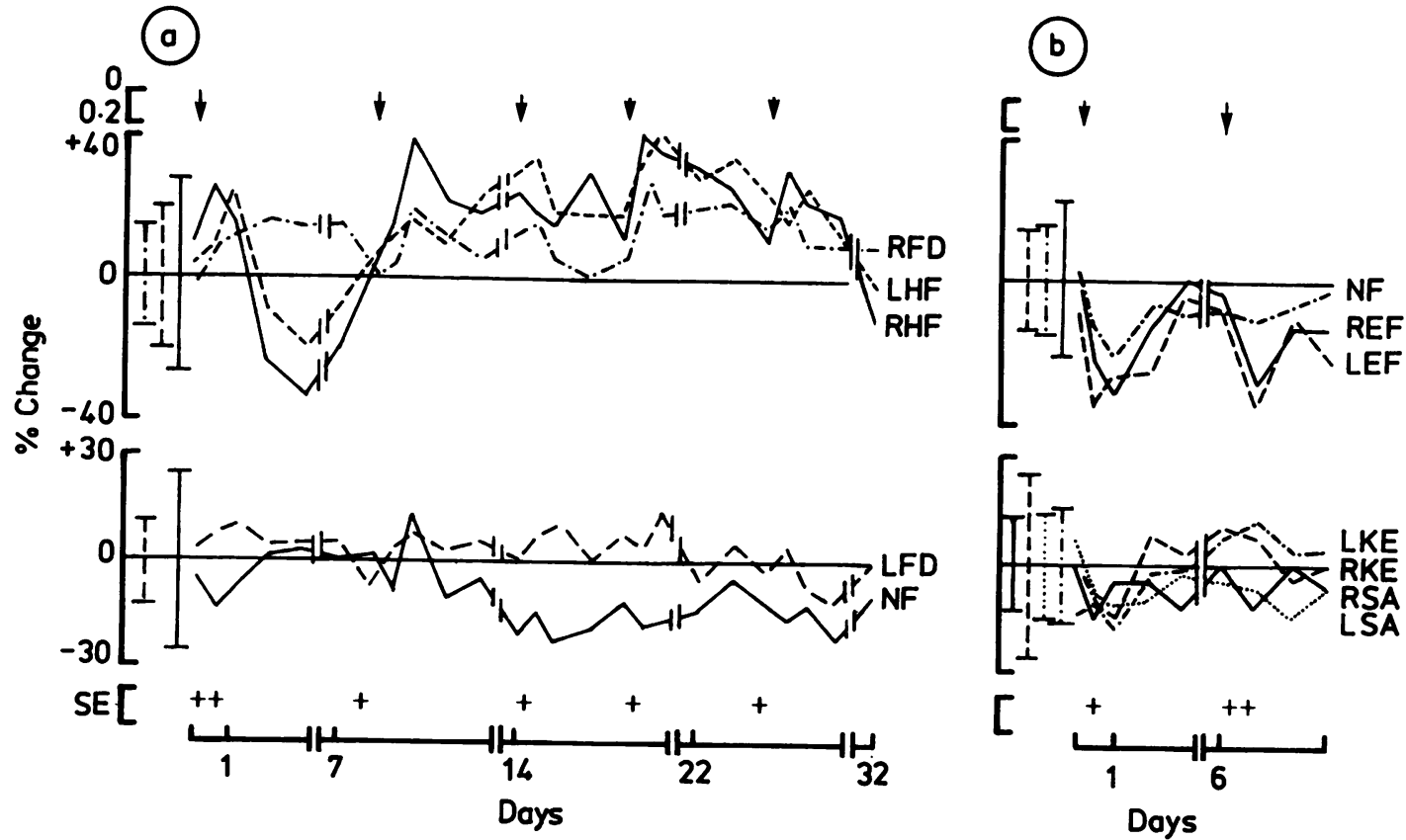

Fig 7 Time course of changes in dynamometry measurements of force. All muscles tested in case 12(a) and case $11(b)$. The layout of the graphs is similar to fig 4. SE = Side effects $(+$ mild, ++ moderate $)$. Top: Muscles which changed (improvement in patient $A$, deterioration in patient B) Bottom: Muscles which did not change. Patient A had also improvement in timed walking and rising from a chair. For muscle name abbreviations see methods; $R=r i g h t, L=l e f t$. The dose range in the top left corner, in $\mathrm{mg} / \mathrm{kg}$, is the same for the two patients and the size of the arrows correlates with the dose given.

patients. Studies with native TRH have shown improvement $^{29}$ or no change ${ }^{10-12}$ in VC. Exacerbation of asthma has been reported..$^{13} \mathrm{~A}$ mean $35 \%$ decrease in $\mathrm{FEV}_{1}$ with TRH compared to saline was found in five of 25 patients in one study ${ }^{14}$ and bronchospasm produced by hyperthyroidism was suggested as the mechanism. Both our two patients with decreased peak flow had raised serum T4 above the normal range. The effect might also be related to a direct effect of TRH on smooth muscle. ${ }^{15}$

The effects seen on cramps and spasticity could be maintained for up to 4 weeks after the last infusion. In a few patients we saw initial increase, followed by decrease, in spasticity. Similar observations have been made with TRH over a shorter period by others. ${ }^{16}$ The response in muscle force was patchy and transient. Some patients had deterioration in one or more muscles and improvement in others. In two patients initial deterioration in some muscles was followed by transient improvement 24-48 hours later. This initial deterioration was associated with more side effects, although the assessments were made at times when they were minimal. In one patient five muscles improved initially but deteriorated with higher doses and again improved with lower doses 4 days later. These patterns of response make analysis of data in large scale studies difficult. Symptomatic improvement for up to 32 weeks $^{16}$ and 10 weeks ${ }^{17}$ with subcutaneous and intravenous open administration of native TRH respectively has been reported. Daily injection of small subcutaneous $(25 \mathrm{mg})$ and intramuscular (4 mg) $)^{1218}$ and of larger intramuscular $(150 \mathrm{mg})$ doses $^{11}$ were reported as of no benefit in controlled trials. In one of them ${ }^{11}$ proximal muscle strength was improved after 16 weeks and in another ${ }^{12}$ fixed assessment points were not stated, reliable baselines were not defined and assessment methods may not have been sensitive enough. In a controlled study ${ }^{10}$ on 14 responders with IV TRH every other day the TRH group had less deterioration than the saline group over 10 weeks in jaw muscle strength, vital capacity, certain tests of lower extremity function and exercise capacity. One group reported no overall benefit with intrathecal TRH over 6 months ${ }^{19}$ whilst another ${ }^{15}$ suggested a slowing of the rate of deterioration in muscle strength over 12 
months. No arrest of disease progression has been seen for TRH and RX77368. One controlled study ${ }^{11}$ with daily im TRH for 2 months showed no slowing of the rate of deterioration by $80 \%$ or more. However, whether a lesser degree of slowing of the rate of deterioration (globally or for certain specific functions) is possible, is not known.

A given drug may be therapeutically useful in MND if, in the absence of serious side effects it is found to (1) reduce mortality, and/or (2) prolong survival time, and/or (3) reduce significantly the rate of deterioration in some or all effected functions, and/or (4) produce symptomatic improvements which can be maintained for prolonged periods. One or more of these conditions can be fulfilled by such a drug acting on the (so far unknown) cause of the disease and/or on the mechanisms leading to motor neuron loss and/or on the mechanisms mediating the symptomatic effects of motor neuron loss or dysfunction. In turn, these possible actions may be exerted on (1) cortical motor neurons and/or their connections and/or (2) bulbar motor neurons and/or their connections and/or (3) spinal motor neurons and/or their connections. It follows that, in MND short lived improvements in function do not necessarily represent therapeutic benefit just as much as lack of detectable symptomatic improvement does not necessarily mean lack of such benefit. Since the usual cause of death in MND is respiratory failure hypothetical drugs acting mainly on limb motor neurons might help disability without affecting survival time or mortality. Conversely, drugs acting mainly on bulbar and high cervical motor neurons might increase survival time although somatic disability would remain unchanged. ${ }^{1}$

Our data suggest that RX77368 may have a more prominent action on bulbar function and less in somatic muscle force, and that beneficial effects may be maintained for several weeks in some patients. Administration of RX77368 did not result in dramatic change in functional status; the effects were slight or moderate but definite. A possible practical value of this or other analogues as symptomatic treatment will need confirmation of our results in a larger series, an acceptable incidence of side effects and a demonstration of persistence of the benefits seen for a few months. Longer term controlled studies with RX77368 on the course of the disease are also required but attention to dose, frequency of administration and assessment methods will be critical.

This work was supported by Grants from the Motor Neurone Disease Association of Great Britain, the NW Thames Regional Health Authority and the Special Trustees of Westminster and Roehampton Hospitals.
We thank Drs C Hawkes, R C Hughes, J Jestico, C Kennard, R McKeran, E Reynolds, A Turner and S Wilson who kindly referred patients for this study and Prof R Farmer for statistical advice.

\section{References}

1 Guiloff RJ. Thyrotropin Releasing Hormone and Motorneurone Disease. Reviews in the Neurosciences 1987; 1(3-4):201-19.

2 Engel WK, Siddique T, Nicoloff JT. Effect on weakness and spasticity in Amyotrophic Lateral Sclerosis of Thyrotropin Releasing Hormone. Lancet 1983;ii: 73-5.

3 Guiloff RJ, Eckland DJA, Demain C, et al. Controlled Acute Trial of a Thyrotropin-Releasing Hormone Analogue (RX77368) in Motor Neurone Disease. $J$ Neurol Neurosurg Pychiatry 1987;50:1359-70.

4 Potvin AR, Tourtellotte WW. Quantitative Examination of Neurologic Functions. Florida: CRC Press, 1985;1: 167-79.

5 Brown RL, Durbin $\mathrm{J}$ and Evans JM. Techniques for testing the constancy of regression relationships over time (with discussion). J Royal Statistical Society (B), 1975;37:149-92.

6 Fleiss JL. Statistical Methods for Rates and Proportions. New York, John Wiley and Sons, 1981:212-32.

7 Ogawa N, Mizumo S, Nukina I, et al. Chronic thyrotropin releasing hormone (TRH) administration on TRH receptors and muscarinic cholinergic receptors in CNS. Brain Res 1983;263:348-50.

8 Simasko SM, Horita A. Treatment of rats with a TRH analogue MK-771. Down Regulation of TRH receptors and Behavioural Tolerance. Neuropharmacology 1985;24:157-65.

9 Konishi T, Sakakibana T, Konayaga M, et al. The effect of TRH on respiratory function in ALS. J Neurol 1985; Suppl 232:35.

10 Brooks BR, Sufit RL, Montgomery GK, et al. Intravenous thyrotropin-releasing hormone in patients with amyotrophic lateral sclerosis. Dose-response and randomized concurrent placebo controlled pilot studies. Neurol Clin 1987;5:143-58.

11 Brooke MH, Florence JM, Heller SL, et al. Controlled trial of thyrotrophin releasing hormone in Amyotrophic Lateral Sclerosis. Neurology 1986;36:146-51.

12 Mitsumoto $\mathrm{H}$, Salgado ED, Negroski $\mathrm{D}$, et al. Amyotrophic Lateral Sclerosis: Effects of acute intravenous and chronic subcutaneous administration of thyrotrophin-releasing hormone in controlled trials. Neurology 1986;36:152-9.

13 Engel WK, Carlo JR, Van den Bergh P, et al. Further clinical studies of TRH in ALS and other motor neuron disorders. Neurology 1984;34(suppl 1):238.

14 Braun SR, Sufit RL, Brooks BR. Pulmonary Effects of Thyrotropin Releasing Hormone in Amyotrophic Lateral Sclerosis. Lancet 1984;ii:529-30.

15 Munsat TL, Taft J, Kasdon D. Intrathecal thyrotropinreleasing hormone in amyotrophic lateral sclerosis. Neurol Clin 1987;5:159-70.

16 Engel WK, Van den Bergh P, Askanas V. Subcutaneous 
Thyrotropin-Releasing Hormone seems ready for wider trials in treating lower motor neurone-produced weakness and spasticity. Ann Neurol 1984;16:109-10.

17 Serratrice G, Desnuelle C, Crevat A, et al. Traitement de la sclérose latérale amyotrophique par le facteur de libération de l'hormone thyréotrope (TRH). Rev Neurol(Paris) 1986;142:133-9.
18 Imoto K, Saida K, Iwamura K, et al. Amyotrophic Lateral Sclerosis: a double blind crossover trial of thyrotropin releasing hormone. J Neurol Neurosurg Psychiatry 1984;47:1332-4.

19 Stober T, Schimrigk K, Dietzsch S, et al. Intrathecal Thyrotropin-releasing hormone therapy of amyotrophic lateral sclerosis. J Neurol 1985;232:13-14.

\section{J.-J. Forst and Lasègue's sign}

Sciatica has been recognised since Greek and Roman times, but only since the paper of Mixter and Barr ${ }^{1}$ has its commonest cause been recognised as a prolapsed lumbar disk.

Ernest Charles Lasègue (1816-83), impecunious student friend of Claude Bernard, favourite pupil of Trousseau, won his agrégation (about GPI) in 1853. Physician to the Salpêtrière he was "forever after malingerers". The notion of uncovering malingerers who simulated sciatica, took root when he watched his son in law Cesbron tuning his violin: "is not the string stretched over the bridge like the sciatic nerve which is made taut on the ischium when the lower extremity is elevated?"

Dr J.-J. Forst's doctoral thesis of $1881^{2}$ described the sign that his teacher Lasègue had observed but never published. There is however a contemporary description by a Serbian physician, Laza Lazarevic in $1880^{3}$ of "Ischias postica contunnii" with restricted straight leg raising. It may be coincidental that Kernig's sign which is often confused with it, was described in $1884^{4}$.

Forst described his master's test in two stages:

"the patient is placed on the bed in the supine position, and we take the foot of the affected limb in one hand... holding the leg in extension, we flex the thigh on the pelvis. Raising the limb only a few centimetres produces a sharp pain at the level of the sciatic notch... We replace the limb and proceed to another manoeuvre which is only a confirmatory test... If we now flex the leg on the thigh, we can flex the thigh on the pelvis without producing any painful sensation." Forst stressed the precautions of flexing the thigh slowly and sliding the heel on the bed and securing cooperation to relax the limb completely.

"What is happening?... the sensation of pulling is very probably due to compression of the sciatic nerve by muscular contraction. On the other hand, if we flex the leg on the thigh, we paralyse the extensors of the thigh on the pelvis.... there is greater ease in raising the limb with less compression of the sciatic nerve... We consider this sign to be pathognomonic of sciatica, for we have not found it in any other affection of that region."

In 1884, De Beurmann espoused the current explanation: that the sign is due to stretching of the sciatic nerve itself rather than sciatic compression by the muscle mass.

\section{References}

JMS PEARCE

1 Mixter WJ, Barr JS. Rupture of the intervertebral disc with involvement of the spinal canal. N Engl J Med 1934;211:210-3.

2 Forst J.-J. Contributions a l'Étude Clinque de la sciatique. Thèse pour le Doctorat en Médecine, Paris: Faculté de Médecine de Paris, 1881. translated In: Lasègue's Sign. Wilkins RH, Brody IA. Arch Neurol 1969;21:219-21.

3 Lazarevič LK. Ischias postica Contunnii: Ein Beitrag zu deren Differential-Diagnose. Allg Wien Med Ztg 1884;29:425-26 et seq.

4 Wartenberg R. Lasègue sign and Kernig sign: Historical Notes. Arch Neurol Psychiat Chic 1951;66:58-60.

5 De Beurmann L. Note sur un signe peu connu de la sciatique: recherches expérimentales. Arch Physiol Norm Pathol $1884 ; 16: 375-80$. 